\title{
The Potential Usage of Language Skills for Predicting Recovery from Persistent Group in Korean Speaking Children Who Stutter
}

\author{
Soo-Bok Lee ${ }^{a}$, Da-Yun Lee ${ }^{b}$, Hyun-Sub Sim ${ }^{\text {b }}$, Dong-Sun Yim ${ }^{b}$ \\ ${ }^{a}$ Department of Speech-Language Therapy \& Aural Rehabilitation, Woosong University, Daejeon, Korea \\ ${ }^{b}$ Department of Communication Disorders, Ewha Womans University, Seoul, Korea
}

Correspondence: Dongsun Yim, PhD Department of Communication Disorders, Ewha Womans University, 52 Ewhayeodae-gil, Seodamun-gu, Seoul 03760, Korea

Tel: $+82-2-3277-6720$

Fax: +82-2-3277-2122

E-mail: sunyim@ewha.ac.kr

Received: October 4, 2018

Revised: November 21, 2018

Accepted: February 8, 2019

This article is based on a part of the first author's master's thesis from Ewha Womans University (2016).
Objectives: Predicting the prognosis of children who stutter during early childhood is critical. Thus, it is of practical and theoretical interest to identify who will recover from stuttering and who will not, yet this is not an easy task due to overlapping surface similarities between these two groups. We investigated whether language skills at the initial visit can predict 18-month outcomes of stuttering severity. We examined both semantic and syntactic profiles that represent cross-linguistic features of Korean. Methods: A longitudinal study obtained children's language skills, such as number of different words (NDW), mean length of C-unit in word (MLC-W), the number of case markers, and the number of connective endings across time periods (initial visit vs. 18 months later). Children received both indirect and direct therapy. A repeated one-way ANOVA, Spearman non-parametric correlation analysis and multiple stepwise regression analysis were used to explore the language predictors that can discriminate between groups. Results: Different linguistic profiles were found between groups. The persistent group performed poorly on language variables at the initial visit, even though they all caught up in 18 months, with the exception of the use of case markers. Qualitative analysis showed different tendencies between groups. It was the number of case markers predicting later stuttering severity level in the persistent group and connective ending was the predictor in the recovered group. Conclusion: Results are discussed in terms of how initial language skills can disentangle children who will recover and persist. Cross-linguistic features important to consider when explaining these results are also highlighted. Additional research on language profile in children who stutter is suggested.

Keywords: Early childhood stuttering, Language, Longitudinal study, Recovered group, Persistent group
Predicting the prognosis of children who stutter during early childhood is critical. The majority of children who stutter have been documented to naturally outgrow their condition (Reilly et al., 2013; Yairi \& Ambrose, 1999). However, the children who continue to stutter and mostly remain in this condition will face challenges, such as reduced vocational and economic potential (Rees \& Sabia, 2014) and negative social-emotional relationship with their peers (Bricker-Katz, Lincoln, \& McCabe, 2009). Thus, it is of prac- tical and theoretical interest to identify who will recover from stuttering and who will not, yet this is not an easy task due to the surface similarities between these two groups.

Prior studies have found several factors to predict the likelihood of a stuttering recovery, including demographic markers (Ambrose, Yairi, Loucks, Seery, \& Throneburg, 2015; Bloodstein, 1995), the time at which the stuttering diagnosis was made (Yairi, Ambrose, Paden, \& Throneburg, 1996), as well as parental education and so- 
cio-economic status (Boyle et al., 2011; Watts, Eadie, Block, Mensah, \& Reilly, 2015). Ongoing research investigates the unique phenotypes of children who stutter, which can predict their later outcomes.

Yairi \& Ambrose (2005) analyzed family history and spontaneous speech samples of stuttering children over the course of 1 year; and found that stuttering children's dysfluency patterns, stuttering persistence duration, age at which stuttering began, and children's expressive language skills all predicted fluency recovery. In other words, children with a history of family stuttering had difficulty in gaining fluency, and children who recovered from stuttering showed a continuous decrease in dysfluency patterns, such as the repetition of partial and one-syllable word and irregular vocalization. Stuttering children who recovered began stuttering much earlier than children with persistent stuttering, and the persistent group showed much lower scores in their overall linguistic skills than the recovered group.

Demographic markers have been implicated in differentiating children who will recover from stuttering and who will persist in stuttering. Ambrose et al. (2015) observed stuttering children, grouped them into a persistent group and recovery group, and children without stuttering. Gender was a key factor in this study, yet no gender differentiation was found between the persistent vs. the recovery group. Also, the average age at which stuttering began, the onset of stuttering, was 36.95 months for the persistent group and 34.26 months for the recovery group. However, these results were not statistically significant. Furthermore, their vocabulary scores and overall language skills were analyzed, and the results showed that the persistent group had significantly lower scores in every aspect, but the mean length of utterance (MLU), which showed the lowest scores, did not show a significant difference between groups. Their communicative attitudes were also analyzed; negative attitudes toward the act of talking were found to be more likely to be passive during a conversation, which might affect the persistence and recovery of stuttering. In other words, children who recovered from stuttering are more likely to be more active and self-advocative during a conversation, but children who persist from stuttering are more likely to be less active during a conversation, at least in regard to speaking.

\section{Language Skills in Predicting Recovery vs. Persistence of Stuttering}

Children who stutter have been documented to have subclinical deficits in language skills (Ambrose et al., 2015). Language skills including receptive and expressive vocabulary size, length of utterance, and complexity of the sentence in children who stutter are usually within normal range, but at a lower end of the normal distribution (Guitar, 2006; Miles \& Bernstein-Ratner, 2001; Muma, 1971; Wall, 1980; Watkins \& Yairi, 1997). Watkins \& Yairi (1997) examined linguistic abilities, especially vocabulary and syntax, in recovery and persistence of stuttering. Participants were divided into a persistent group, fast recovered group, and slow recovered group. Their MLU, number of different words (NDW), and number of total words (NTW) were collected twice over the year of the experiment, and the results showed that children's expressive language was within the normal range. Thus, no difference was found between the groups. Furthermore, another study by Watkins, Yairi, \& Ambrose (1999) collected spontaneous speech samples of the persistent group and the recovered group and claimed that no significant group differences were observed regarding the MLU and NDW of the two groups.

However, others have found significant differences between the persistent group and the recovered group. Weiss \& Zebrowski (1994) carried out a story retelling task on stuttering children and typically developing children. They discovered that both groups showed similar story lengths and story content. However, qualitative differences within the story telling were observed. When typically developing children were asked to retell the story to someone who had not heard the story before, their utterances were much longer and detailed, whereas stuttering children showed similar length of utterances whether the listener was familiar or unfamiliar with the story. According to Weiss \& Zebrowski (1994), this was because the child limited his utterances on their own to reduce the dysfluency. On the other hand, Bajaj (2007) compared the story length and narrative ability between early stuttering children and typically developing children. A narrative scoring scheme in stuttering children was significantly lower than that of typically developing children, and the conversation of stuttering children was concluded to fall behind compared to typically developing children.

Leech, Bernstein-Ratner, Brown, \& Weber (2017) conducted the 
most up-to-date research examining language skills as a key factor in predicting recovery outcomes of children who stutter. The unique feature of this study was that they investigated the growth in the productive language performance to disentangle the groups into children who recover and children who persist in stuttering. They calculated the productive syntax and vocabulary diversity growth, and the results showed different linguistic profiles between children who recovered from stuttering and children who persist in stuttering for which the syntactic growth was a significant predictor for the recovered group.

Many studies (Ambrose et al., 2015; Bajaj, 2007; Guitar, 2006; Miles \& Bernstein-Ratner, 2001; Muma, 1971; Wall, 1980; Watkins \& Yairi, 1997; Watkins et al., 1999) showed results for children who stutter to have lower language skills than typically developing children, and very few studies have found a positive relation between language skills and recovery state from stuttering (Leech et al., 2017; Ntourou, Conture, \& Lipsey, 2011). However, we still need to further investigate what would be the predicting factor for the stutter recovery process of a late diagnosed child as opposed to a child who receives a diagnosis during their first clinical visit. We also need to explore children who go through multiple prototypical steps, such as an evaluation and intervention phase - the initial assessment procedure, indirect therapy and then, if nothing works, move onto direct therapy. In our study, children received indirect therapy and direct therapy if needed after the initial evaluation. We also need to know whether the findings for English speaking children who stutter are similar to those who speak different languages, such as Korean, since language skills can be very specific to the language itself. If language skills, such as grammatical markers or syntactic complexity, are important features to consider when predicting stuttering recovery, then an Asian language such as Korean, which is very different from English, needs to be evaluated. For example, the Korean mean length clause-word (MLC-w) is more accurate than the MLU in predicting the complexity of the sentence structure because subject and verbs in Korean can be missing from the sentence when both communicating partners know what the missing words are implied to be. Thus, C-unit is a good indicator in Korean compared to the mean length of the sentence. In addition, the case markers and connective endings are a unique feature for Korean syntactic markers when assessing lan- guage skills. Because of this, we need to confirm whether common features across languages, such as semantics indicated by vocabulary and syntactic skills indexed by MLC-w and also unique features such as case markers and connective endings in Korean, can be important factors to successfully identify the recovered group from the persistent group.

In the current study, we collected spontaneous speech samples of stuttering children during an 18-month period, who initially visited the laboratory and received indirect therapy. If children continuously showed dysfluency, even after indirect therapy, they then went through direct therapy. At the final point, during which the direct therapy session was terminated, a spontaneous speech sample was again obtained from the children. From the spontaneous speech, NDW, the number of MLC-w, the number of case markers, and the number of connective endings were analyzed. Ultimately, we aim to explore whether there are any differences in the variety of vocabulary usage and syntactic abilities between the persistence and recovered groups.

This study investigated the recovery after stuttering treatment rather than the natural recovery and Korean characteristics of stuttering children unlike previous studies.

Our specific research questions were as follows.

(1) Are there significant differences in language skills indicated by NDW, the number of MLC-w, the number of case markers, and the number of connective endings, between the persistent group and the recovered group across time periods (initial visit vs. 18 months later)?

(2) Do language skills from the initial visit correlate and/or predict the stuttering severity 18 months later?

\section{METHODS}

\section{Participants}

In total, the participants included 18 stuttering children (10 boys and 8 girls) whose chronological age was between $2 ; 3$ years old (27 months) and 5;4 years old (64 months). Participants who were selected as subjects were tested according to the following. All children were tested on the Paradise-Fluency Assessment II (P-FA-II; Sim, Shin, \& Lee, 2010) and Receptive \& Expressive Vocabulary Test (REVT; Kim, Hong, Kim, Jang, \& Lee, 2009), and then the 
subjects were evaluated on their ability, and excluded if they did not meet the selection criteria. Children who were selected as subjects received an intervention, for the purpose of data collection. The data was comprised of things such as parents' education, indirect treatment, direct treatment, and interaction play utterances and this information was gathered and analyzed twice (initial visit and 18 months later).

All the participants met the following conditions. (1) Parents reported the child's stuttering. (2) According to the parents' report, stuttering was first observed within the past 12 months. (3) The children scored moderate or higher on the P-FA-II (Sim et al., 2010) and were diagnosed with fluency disorders. (4) On the REVT (Kim et al., 2009), the child's percentile score for receptive language was at or above -1 SD. (5) The children were not accompanied with any other disabilities, such as vision, hearing, neurologic, or emotional. Demographic information of the participants is shown in Table 1. See Appendix 1 for more information.

Table 1. Demographic information on recovered group and persistent group

\begin{tabular}{lcc}
\hline Characteristic & $\begin{array}{c}\text { Recovered group } \\
(\mathrm{N}=11)\end{array}$ & $\begin{array}{c}\text { Persistent group } \\
(\mathrm{N}=7)\end{array}$ \\
\hline Sex & & 4 \\
Male & 6 & 3 \\
Female & 5 & $42.5 \pm 8.4$ \\
Age at initial visit (mo) & $44.0 \pm 9.75$ & $38.0 \pm 11.4$ \\
Age at onset (mo) & $38.7 \pm 11.3$ & $4.5 \pm 4.2$ \\
Estimated time post-onset (mo) & $5.8 \pm 3.7$ & $4.2 \pm .7$ \\
Stuttering severity (score) & $3.6 \pm .5$ & $49.4 \pm 15.8$ \\
REVT test (score) & $50.6 \pm 11.8$ & \\
Therapy & & $18.0 \pm .0$ \\
Duration of therapy (mo) & $14.4 \pm 5.4$ & $0(0)$ \\
Indirect only therapy & $2(18.0)$ & $7(100)$ \\
Both indirect and direct therapy & $9(82.0)$ &
\end{tabular}

Values are presented as mean $\pm S D$ or number $(\%)$.

REVT = Receptive \& Expressive Vocabulary Test (Kim, Hong, Kim, Jang, \& Lee, 2009). a Stuttering severity score $(1=$ very mild, 2 = mild, $3=$ moderate, $4=$ moderate-severe, $5=$ severe) measured Paradise-Fluency Assessment II (Sim, Shin, \& Lee, 2010).

\section{Treatment Contents}

The treatment of stuttering children is divided into indirect treatment and direct treatment. Parent education is first received, followed by indirect treatment and direct treatment (Lee \& Sim, 2015). Stuttering children and their parents participated in the following treatments (See Table 2 for the flow of the treatment procedure). First, parents in the parent education program received educational counseling. Parents of children who stutter were counseled with correct and precise information about stuttering in order to help them identify stuttering correctly and to counter any misleading preconceptions about stuttering in children (Manning \& DiLollo, 2018). Second, during the 12 weeks of indirect treatment sessions, parents learned how to improve their fluency by changing their own speech and language. After the indirect intervention was over, P-FA-II was used to assess each individual child's stuttering severity level.

If children were diagnosed as having stuttering from the evaluation at 12 weeks after indirect treatment, then, they received a direct treatment. However, if children were diagnosed as 'mild' on the P-FA-II, and parents reported that the child was no longer considered to have a stutter, then the treatment was terminated for the children. Two children in the recovered group were terminated from the program after indirect treatment. Third, for direct treatment, the parents participated as observers during treatment or participated in concurrent indirect treatment.

Eighteen months after the pre-test, the participants were divided into the persistent group and the recovered group based on the following criteria.

\section{Persistent group}

The stuttering persistent group showed consistent dysfluency for 18 months after participating in the research. The persistent stuttering group met the following criteria: after the research had

Table 2. Research progress schedule

\begin{tabular}{llc}
\hline Research time & Treatment information & Data collection \\
\hline Initial visit (evaluation) & & Fluency formal test \& language formal test \\
1st parent-child interaction assessment (pre) & Parent education & - \\
After 1 month & Interaction therapy start (12-week program) \\
After 1.5 months & Direct therapy start & - \\
After 5 months & & 2nd parent-child interaction assessment (post) \\
After 18 months &
\end{tabular}


been terminated, (1) an speech-language pathologist (SLP) diagnosed him/her as having a stutter, (2) parents were aware of the child's stuttering, (3) atypical dysfluency is observed more than three times in 100 syllables from the child's utterance, and (4) children scored moderate or higher on the P-FA-II after 18 months of participating in the current study.

\section{Recovered group}

A child being placed in the recovered group meant that their dysfluency decreased or was hardly seen for 18 months after participating in the research. The recovered group met the following criteria: after the research had been terminated, (1) the SLP diagnosed that no signs of stuttering were observed, (2) parents acknowledged that the child does not stutter, (3) atypical dysfluency is observed less than three times in 100 syllables from the child's utterance, and (4) children scored 'mild' or lower in the P-FA-II after participating for 18 months in the current study.

The mean age of stuttering recovery was $44.0 \pm 9.75$ months, and the stuttering persistence was $42.5 \pm 8.4$ months. No significant differences were observed between the groups regarding age. The mean age at the onset of stuttering, in which there was no significant difference, was $38.7 \pm 11.3$ for the recovered group and $38.0 \pm 11.4$ for the persistent group. The stuttering severity for the recovered group was $3.6 \pm 0.5$ and $4.2 \pm 0.7$ for the persistent group on the standardized measurement of the dysfluency test, P-FA-II, and there were no group differences. Finally, both of their receptive vocabulary scores as measured by REVT showed no significant group difference. However, there were two children from the recovered group who received indirect therapy and did not need to go through direct therapy since they met the criteria for the recovered group (Table 1). Two patients in the recovery group completed the treatment after the indirect treatment, and one was recovered at the 12 months after the indirect treatment and the direct treatment after the first evaluation.

\section{Procedure}

Spontaneous speech samples were collected via parent-child interaction. They played with toys that the children were familiar with, such as zoo animal toys and Playdoh. Parents were instructed to play as if they were playing at home. The parent-child inter- action session lasted about 15-30 minutes, and 50 utterance speech samples of the child and the parent were collected twice. At the time of the evaluation, P-FA-II, REVT, and parent-child interactive style were also conducted.

The main caregivers of all households received parent training, which lasted about 2 hours after the initial assessment. During the parent training, stuttering and fluency were explained using a DVD, and then the participants watched a video regarding a successful case study of parent-child treatment. In addition, they went through speech control practice and Q\&A sessions, in which they had the opportunity to ask any questions pertaining to the tasks.

\section{Experimental Tasks}

Parental utterances included in the child's 100 utterances and child utterances in the parent-child interaction assessment were collected twice. Parent-child interaction evaluations used activities familiar to the children, such as 'zoo play' and 'clay making'. When the child was short of speech, or when the child was indifferent to the toys, they collected data using their favorite toys. Before starting play, parents were asked to "play like at they were at home' so that they could be in a natural play situation.

12 weeks of indirect intervention began 1.5 months after the initial assessment. During the first 6 weeks, the parent and child came to the laboratory once a week and spent one hour of interactive play. The parents received an explanation of the assessment results and treatment plan on the very first therapy session, and the parent's interactive style and environmental factors that may influence stuttering were analyzed. In addition, parents watched the assessment video to establish treatment goals and to assess the parent-child interactive play. Then, assignments that can be done at home were given for the following week.

During weeks 2 through 5, fluency and progress checks were done, the session goals were established and interactive play and assessments were conducted twice. Then, the assignment for the following week was given.

During week 6, the session goal was established, parent-child interactive play was carried out, and parent-child interaction play video was analyzed and compared between weeks 1 and 6. Then the remaining issues were discussed, and the remaining sessions were accordingly planned. 
During the 7th through 11th weeks, the parents filled out a fluency achievement report they had carried out at home and sent it to the clinician. This report was followed up by telephone counseling between the clinician and the parents. During week 12 , a reassessment of the children's fluency and future treatment plan was established. A total of 12 weeks of indirect therapy ended 3 months after the initial evaluation.

A direct intervention began for those of who did not recover from their stutter. This was determined 5 months after the initial evaluation. Direct intervention occurred twice a week, 40 minutes per session, in a 3-phase program. A direct intervention was implemented based on the child's perception and response to stuttering.

At 18 months after the initial evaluation, P-FA-II to measure the children's stuttering severity and the parent-child's post-interaction was conducted to obtain language samples.

\section{Data Analysis}

All dependent variables were analyzed using the Morpheme Analyzer 2.0. To calculate the NDW of the 50 utterances speech samples, utterances, number sequences, or chants, the unintelligible or unclear samples were excluded from the analysis, but any other words that were intelligible were included in the analysis. Predicate elements were counted as one word, and stuttering repetition words were counted as one word as well. The remaining utterances were analyzed based on the word sorting method. The number of C-units were divided by the total number of words to obtain the MLC-w. The word definition for the MLC-w production was analyzed according to the word sorting method presented in Kim (1997). Of the 50 collected speech samples, the number of case markers, frequency of connective endings and NDW were calculated.

\section{Statistical Analysis}

A repeated mixed ANOVA was used to identify whether there were significant differences in linguistic factors across time periods (initial visit vs. 18 months later) between the two groups. Mauchly's sphericity test was also utilized to test if the data met the sphericity assumption. Second, Spearman non-parametric correlation analysis and multiple stepwise regressions were used to explore whether language skills from the initial visit could accurately predict their stuttering severity 18 months later.

\section{Intervention Fidelity}

The following method was applied to ensure uniformity of intervention. First, the researcher and the SLP B, C, D, and E obtained the same homogeneity of the treatment composition and procedure by clinical training for evaluation and treatment of the same fluency disorders at the same clinical setting. Second, at the initial visit and 18 months after the evaluation of the interaction, the researcher examined the status of the subjects and treatment contents with B, C, D, and E. Discussion was made and reflected in the treatment. Third, the intervention success rate among the SLPs was $50 \%$ or more except for the (SLP) D, and there was no difference in intervention according to the SLPs. In the case of the (SLP) $\mathrm{D}$, the pathologist treated only one subject and the subject was in the persistent group resulting in an abnormally low success rate and possibly misleading data (if taken out of the context of quantity of subjects and the experiment as a whole).

\section{Reliability}

The reliability of the linguistic aspects of spontaneous utterances speech samples was determined by randomly selecting $20 \%$ of the total subjects and analyzing them independently. The first evaluator was a researcher and the second evaluator was a graduate student who completed a master's course in speech language pathology.

The NDW's reliability was $94.87 \%$, the MLC-w's reliability was $94.52 \%$, the case marker's reliability was $94.73 \%$, and the connective ending's reliability was $100 \%$.

\section{RESULTS}

Table 3 shows the mean and SD of both groups for NDW, MLC$\mathrm{w}$, the number of case markers, and the number of connective endings. The data is summarized as 'pre' vs. 'post' in which 'pre' indicates initial visit data before the treatment started and 'post' indicates 18 months later after the initial visit had been conducted.

\section{Group Performance on NDW}

There were no main effect of the group $\left(F_{(1,16)}=3.68, p>.05\right)$ on 
Table 3. Descriptive statistics for NDW, MLC-W, case markers, and connective endings of group by time period

\begin{tabular}{lccccc}
\hline & \multicolumn{2}{c}{ Recovered group (N=11) } & & \multicolumn{2}{c}{ Persistent group (N=7) } \\
\cline { 2 - 3 } \cline { 5 - 6 } & Pre & Post & & Pre & Post \\
\hline NDW & $66.54(5.2)$ & $73.72(4.0)$ & & $44.85(4.2)$ & $72.59(4.6)$ \\
MLC-w & $2.54(.2)$ & $2.89(.2)$ & & $1.85(.1)$ & $2.95(.2)$ \\
Case markers & $18.81(2.7)$ & $25.0(3.0)$ & & $11.85(1.2)$ & $18.57(2.7)$ \\
Connective endings & $12.0(2.9)$ & $10.72(1.7)$ & & $4.14(1.9)$ & $12.28(2.0)$ \\
\hline
\end{tabular}

Values are presented as mean (standard error).

Pre = initial visit; Post $=18$ months visit; NDW=number of different words; MLC$\mathrm{W}=$ mean length of $\mathrm{C}$-unit in word.

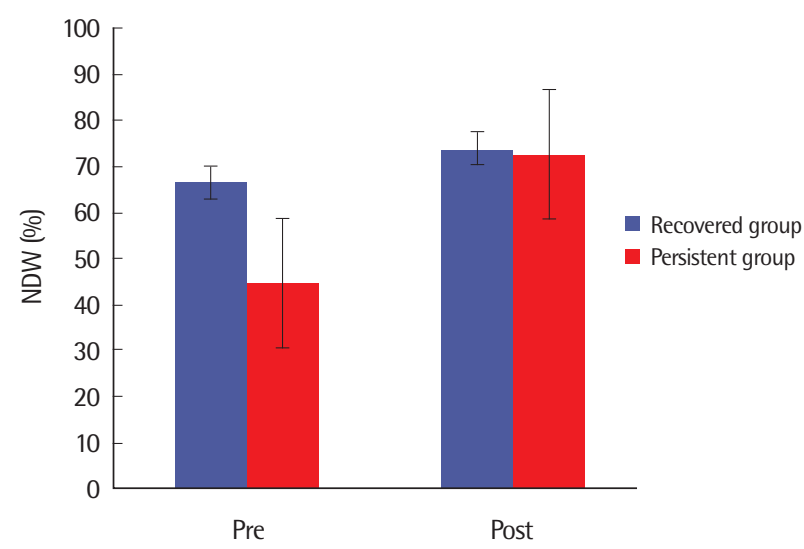

Figure 1. Number of different words (NDW) performance of group.

Pre $=$ initial visit; Post $=18$ months visit.

NDW. However, there was a statistically significant difference in the time period $\left(F_{(1,16)}=26.60, p=.000\right)$ in which the NDW mean was $55.7 \pm 14.23$ at the initial visit and $73.14 \pm 12.73$ at the final visit. A statistically significant interaction was also found $\left(F_{(1,16)}=9.21\right.$, $p=.008$ ) by the group and time period in which significant group differences were observed at the initial visit (NDW: 66.54 \pm 17.31 of the recovered group and $44.85 \pm 11.15$ of the persistent group), but both groups performed similarly 18 months later $(73.72 \pm 13.34$ of the recovered group; $72.59 \pm 12.13$ of the persistent group). The results of the NDW group performance by time period is shown in Figure 1.

\section{Group Performance on MLC-w}

For the MLC-w, there was no main effect of the group $\left(F_{(1,16)}=\right.$ $2.07, p>.05)$, but there was a main effect for the time period $\left(F_{(1,16)}=\right.$ $18.40, p=.001)$ in which the mean for the initial visit was $2.19 \pm .51$ and that of the final visit was $2.92 \pm .55$. There was a statistically significant interaction $\left(F_{(1,16)}=4.98, p=.04\right)$. The MLC-w mean at

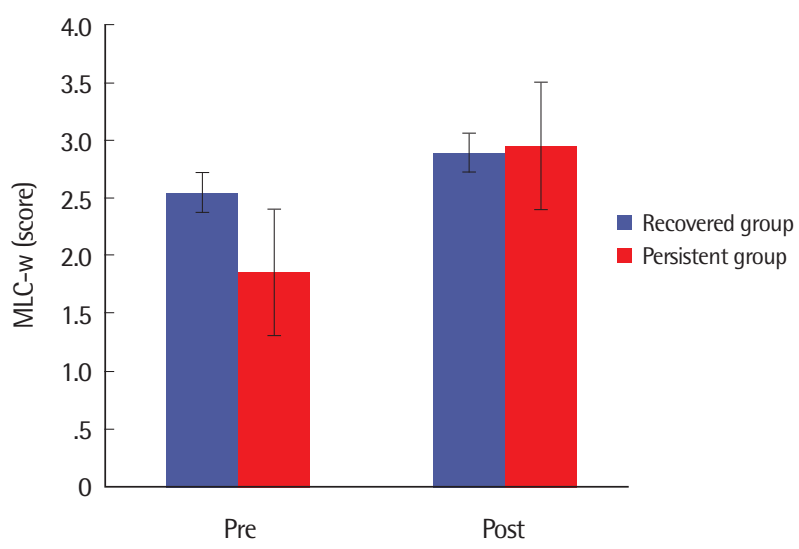

Figure 2. Mean length of C-unit in word (MLC-w) performance of group. Pre $=$ initial visit; Post $=18$ months visit.

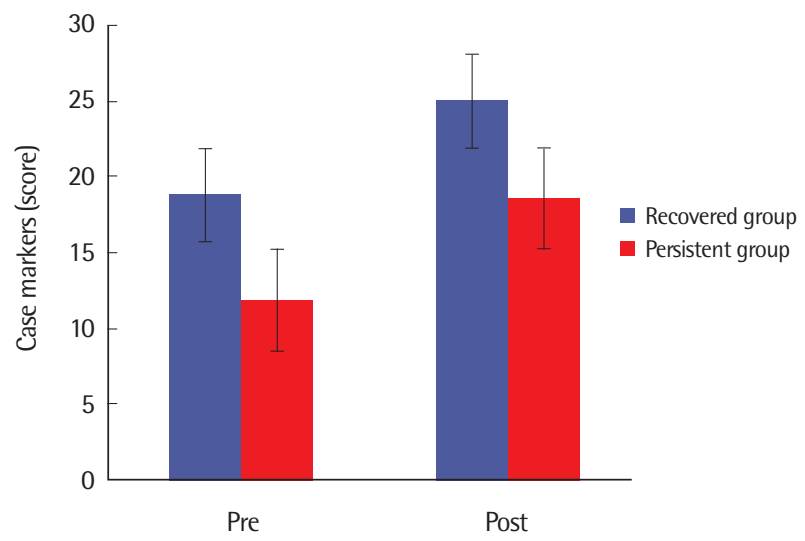

Figure 3. Case marker performance of group. Pre $=$ initial visit; Post $=18$ months visit.

the initial visit of two groups was $2.54 \pm .69$ for the recovered group and $1.85 \pm .33$ for the persistent group. However, both groups had no difference at the final visit in which the recovered group showed an MLC-w mean of $2.89 \pm .55$ and the persistent group showed $2.95 \pm .54$. Figure 2 shows the MLC-w group performance by time period.

\section{Group Performance on Case Markers}

There was a slightly different pattern for the results of the case markers. There was a statistically significant difference between the two groups in this regard $\left(F_{(1,16)}=384.46, p=.025\right)$. The mean of the recovered group was $21.90 \pm 9.50$, and the persistent group showed a mean of $15.21 \pm 5.80$. Additionally, there were statistically significant differences in the time period $\left(F_{(1,16)}=355.718\right.$, $p=.042)$ in which the mean of the initial visit was $15.33 \pm 6.03$ and 
that of the final visit was $21.78 \pm 8.56$. Finally, there were no interaction effects by group and time period $\left(F_{(1,16)}=0.60, p>.05\right)$. The

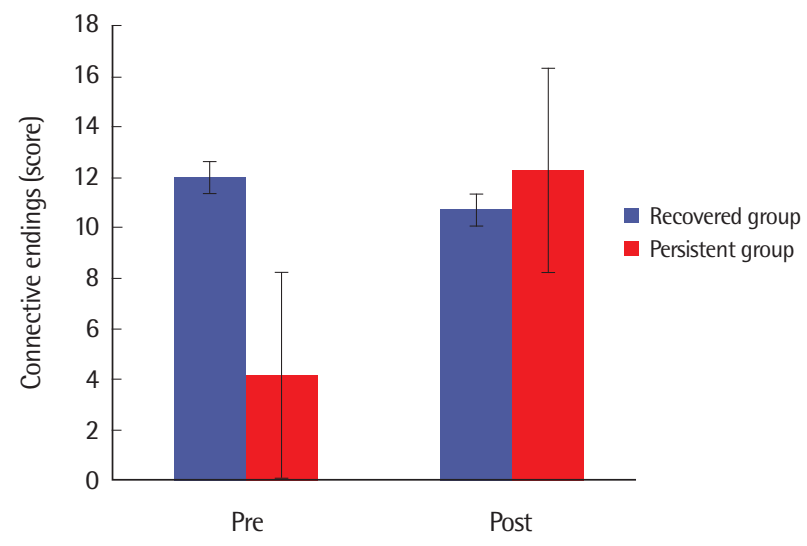

Figure 4. Connective endings performance by groups. Pre $=$ initial visit; Post $=18$ months visit. results of the case markers by group and time period is shown in Figure 3.

\section{Group Performance on Connective Endings}

For the connective endings use, there was a statistically significant interaction effect by group and time period $\left(F_{(1,16)}=5.16, p=.03\right)$. There was a significant group difference at the initial visit in which the mean of the recovered group was $12.00 \pm 9.56$ and that of the persistent group was $4.14 \pm 5.04$. However, both groups showed similar results at the final visit in which the recovered group mean was $10.72 \pm 5.60$ and the persistent group mean was $12.28 \pm 5.34$. There were no significant differences between the time period $\left(F_{(1,16)}=\right.$ $2.74, p>.05)$ and no main effect of the group $\left(F_{(1,16)}=1.40, p>.05\right)$ (Figure 4).

Table 4. Correlation matrix in the recovered group

\begin{tabular}{|c|c|c|c|c|c|c|c|c|c|c|}
\hline & NDW_pre & NDW_post & MLC-w_pre & MLC-w_post & CM_pre & CM_post & CE_pre & CE_post & P-FA-II_pre & P-FA-II_post \\
\hline NDW_pre & & .562 & $.940^{* *}$ & .442 & $.677^{*}$ & .425 & .580 & .246 & -.500 & .289 \\
\hline NDW_post & & - & .344 & $.927^{* *}$ & .025 & $.796^{* *}$ & .533 & .448 & -.267 & .253 \\
\hline MLC-w_pre & & & - & .213 & $.816^{* *}$ & .274 & $.627^{*}$ & .041 & -.411 & .316 \\
\hline MLC-w_post & & & & - & -.081 & $.886^{* *}$ & .484 & $.691^{*}$ & -.015 & .315 \\
\hline CM_pre & & & & & - & -.128 & .463 & -.144 & -.342 & .370 \\
\hline CM_post & & & & & & - & .542 & $.608^{*}$ & .046 & .376 \\
\hline CE_pre & & & & & & & - & .171 & -.166 & $.692^{*}$ \\
\hline CE_post & & & & & & & & - & .120 & .407 \\
\hline P-FA-II_pre & & & & & & & & & - & -.297 \\
\hline P-FA-II_post & & & & & & & & & & - \\
\hline
\end{tabular}

$\mathrm{NDW}=$ number of different words; MLC-W= mean length of C-unit in word; $\mathrm{CM}=$ case markers; $C E=$ connective endings; $\mathrm{P}-\mathrm{FA}-\|$ =the Paradise-Fluency Assessment II (Sim, Shin, \& Lee, 2010).

${ }^{*} p<.05,{ }^{* *} p<.01$.

Table 5. Correlation matrix in the persistent group

\begin{tabular}{|c|c|c|c|c|c|c|c|c|c|c|}
\hline & NDW_pre & NDW_post & MLC-w_pre & MLC-w_post & CM_pre & CM_post & CE_pre & CE_post & P-FA-II_pre & P-FA-II_post \\
\hline NDW_pre & & .417 & .416 & .107 & .426 & .480 & .684 & .157 & .332 & -.330 \\
\hline NDW_post & & - & .300 & .674 & .136 & .166 & -.080 & .128 & -.207 & -.181 \\
\hline MLC-w_pre & & & - & .451 & $.894^{* *}$ & -.044 & .370 & .315 & .667 & -.645 \\
\hline MLC-w_post & & & & - & .519 & .394 & .206 & .666 & .030 & -.517 \\
\hline CM_pre & & & & & - & .264 & .634 & .651 & .729 & $-.857^{*}$ \\
\hline CM_post & & & & & & - & .151 & .602 & .234 & -.694 \\
\hline CE_pre & & & & & & & - & .604 & .433 & -.483 \\
\hline CE_post & & & & & & & & - & -.151 & $-.761^{*}$ \\
\hline P-FA-II_pre & & & & & & & & & - & -.627 \\
\hline P-FA-II_post & & & & & & & & & & - \\
\hline
\end{tabular}

NDW = number of different words; MLC-W=mean length of C-unit in word; CM=case markers; $C E=$ connective endings; P-FA- $I$ = the Paradise-Fluency Assessment II (Sim, Shin, \& Lee, 2010).

${ }^{*} p<.05,{ }^{* *} p<.01$. 


\section{Correlations on Language Skills}

Spearman nonparametric correlation analysis indicated that there was a significant, positive correlation between the connective endings-pre and P-FA-II-post $(r=.692, p<.05)$ for the recovered group. However, it was the case markers-pre $(r=-.857, p<.05)$ which were statistically significant and P-FA-II-post was statistically significant for the persistent group (Tables 4 and 5 for the recovered group and the persistent group, respectively). All language skills including, NDW, MLC-w, the number of case markers, and the number of connective endings from the initial visit were entered into the stepwise regression analysis to explore which variable explained the variance of the final visit of the P-FA-II score. For the recovered group, connective ending-pre explained $47.8 \%$ of the variance of P-F-II score-post $(p=.018)$. For the persistent group, it was the number of case marker-pre that significantly explained the variance of post P-FA-II $\left(R^{2}=.735, p=.014\right)$.

\section{DISCUSSION \& CONCLUSION}

Our study explored pre-intervention language skills to determine the predictors of potential indications of risk for persistent stuttering. The study lasted 18 months in order to keep track of children's initial scores for stuttering and other language skills, and to provide children who had a stutter with indirect and direct therapy. In the final stage of the study, we divided the group into two, the recovered group and the persistent group, based on the clinical judgment and other criteria outlined above. Two of the persistent group recovered at 10 and 12 months, and they terminated therapy during the direct treatment.

The study added new cross-linguistic findings in which the linguistic features that are important in Korean were found to be critical to predict children's recovery vs. persistency later on.

The most outstanding results from the group comparisons were that there was a significant interaction effect between the group and time period (pre-post), which was due to the lower performance of the persistent group. The NDW which represents semantic skills and MLC-w and connective endings that indicate the syntactic skills, were found to be poor in the persistent group, when measured at the initial visit. However, after 18 months both groups showed no difference in these measures, which means that both groups performed well. These results suggest that language skills during the initial visit can disentangle the recovered group from the persistent group (Leech et al., 2017). As found in Leech et al. (2017), it was connective endings which predicted who will be in the recovery group. However, in the aforementioned study, lexical diversity was not found as a significant indicator as was the case in our study. Thus, our study also supported the evidence that syntactic (linguistic) markers are critical in predicting the recovery group. Because of this, for Korean children with a stutter, case markers are also important indicators to pay attention to.

The number of case markers was another key factor that could predict persistence in stuttering, since there were significant group differences where the persistent group performed statistically significantly worse than the recovered group, which lasted until the end of the therapy session. For other measures of language skills, such as NDW, MLC-w, and connective endings, the persistent group caught up with the recovered group at the final point, 18 months after the first visit and after the direct intervention. However, the persistent group never caught up with the recovered group in regards to the use of case markers. The recovered group used case markers significantly more from the beginning, and their excess use, compared to the other group, only increased as the analysis and trial progressed. In Korean, case markers can be omitted, and children generally use sentences without case markers - e.g., "Mommy, I want to eat the apple" - Umma (mommy), $\mathrm{Na}$ (I), Sagwa (apple) Meuko (eat) Shipau (want to). In this example sentence, the strict grammatical sentence should look as follows: "Umma, Nanun (subject case marker), Sagwa-rul (object case marker) Meuko Shipau". Thus, there have to be two case markers, the subject case markers 'nun' and object case markers 'rul'. Even if we omit the case markers, no one would think the sentence is not grammatical nor do people have a hard time understanding each other. However, case markers are important linguistic markers when clinicians and researchers pay attention since children with language impairments have limited proficiency in using case markers (Chun \& Yim, 2017). They not only omit too much, but they use the case markers incorrectly. Thus, in Korean, case markers are an important index for language impairment. It is a critical finding that specific Korean markers, case markers, for language impairment were the indicator for grouping children with persistent and with recovery. 
We were interested in finding whether any language factors from the initial visit could predict the final (18 months) stuttering severity within the group. When we analyzed the data more qualitatively and divided the group into the recovered group and the persistent group, interesting results were found. The persistent group and the recovered group showed different tendencies in predicting the stuttering severity at the 18 months period after the intervention had been completed. In the persistent group, it was again very Korean specific linguistic markers, case markers and connective endings, which significantly correlated the stuttering severity at 18 months. When we ran the regression analysis, the case markers significantly predicted the stuttering severity at the post intervention session. Our results suggest that children who stutter and have greater difficulty in using case markers, which are important for Koreans, will have a higher chance of persisting dysfluency. The results are based on children who did not recover and thus, other variables such as case endings, NDW, and MLC-w were found to be important. In the initial assessment, three children in the persistent group (PER4, PER5, and PER6) were 27, 63, and 30 months old, and the language development was rapidly progressing except the PER5 child. NDW, MLC-w, case markers, and connective endings' pre and post values were more than two times higher than those of the recovered group. In PER 5 child, NDW, MLC-w, and connective endings showed a similar pattern but showed a decreasing tendency in case markers.

However, in the recovered group, the connective ending was significantly correlated with the stuttering score at the 18 months period. As a result, the connective endings from the initial visit predicted the post stuttering severity score. Our results indicate that there is still a wide variation within the group of children who recovered from stuttering. Our data suggests that recovered group who used less connective endings tend to be more fluent 18 months later. These findings are very unique in that children who started off stuttering and recovered later on are more strategic in manipulating the utterance by using the connective endings less, which led to shorter sentences. It is true that shorter sentences have a lower cognitive load for children (Logan \& Conture, 1995; Zackheim $\&$ Conture, 2003). Whether consciously or unconsciously, children might have used trade-offs where they use short sentences by using connective endings less. We should pay more attention to syn- tactic complexity, since children in the persistent group used fewer case endings at the initial visit in our study (Ambrose et al., 2015; Bajaj, 2007). Thus, from the initial visit, it is difficult to say whether the child will recover or persist solely based on connective endings, because there may be an overlapping performance on this measure. We may have to consider other variables when predicting children who will recover from children who will not.

Our results indicate that a longitudinal study may be a more informative and sensitive measure to better understand the connection between the initial features that we as clinicians and researchers observe and the end face of this population.

Future studies are warranted to confirm our findings with more children in the experiment. We also need more data from those who speak other languages to find a common ground across languages and cultures to efficiently identify and support children who have persistent stuttering. Finally, a confirmation study is needed to test whether our findings can accurately predict children who will recover and children who will persist beforehand by using a perceptive analysis.

In summary, our intention to explore language predictors to disambiguate children who persist in stuttering and children who recover from stuttering used four different methods to assess language skills, some of which included Korean specific markers. We found promising results from language skills between the groups in which we may be able to detect the probability of recovery or persistency using solely data from the initial evaluation. We also found unique cross-linguistic features important to better explain the difference between these groups. Our study approach adds a new view to qualitatively examine the persistent group and that of the recovery group.

The limitations of this study and suggestions for subsequent research are as follows. First, it is difficult to generalize the results of the study because the number of children is small. Therefore, the number of subjects should be increased and the level of language ability according to the child's development should be considered. Second, this study did not reflect factors related to caregivers who had the greatest influence on stuttering children.

\section{REFERENCES}

Ambrose, N. G., Yairi, E., Loucks, T. M., Seery, C. H., \& Throneburg, R. (2015). 
Relation of motor, linguistic and temperament factors in epidemiologic subtypes of persistent and recovered stuttering: initial findings. Journal of Fluency Disorders, 45, 12-26.

Bajaj, A. (2007). Working memory involvement in stuttering: exploring the evidence and research implications. Journal of Fluency Disorders, 32(3), 218-238.

Bloodstein, O. (1995). A handbook on stuttering (5th ed.). San Diego, CA: Singular Publishing Group.

Boyle, C. A., Boulet, S., Schieve, L. A., Cohen, R. A., Blumberg, S. J., YearginAllsopp, M., ... \& Kogan, M. D. (2011). Trends in the prevalence of developmental disabilities in US children, 1997-2008. Pediatrics, 127(6), 10341042.

Bricker-Katz, G., Lincoln, M., \& McCabe, P. (2009). A life-time of stuttering: How emotional reactions to stuttering impact activities and participation in older people. Disability and Rehabilitation, 31(21), 1742-1752.

Chun, S., \& Yim, D. (2017). A comparative study of chunking mechanism in children with and without language delay. Communication Sciences \& Disorders, 22(2), 233-244.

Guitar, B. (2006). Stuttering: an integrated approach to its nature and treatment. Philadelphia, PA: Lippincott Williams \& Wilkins.

Kim, Y. T. (1997). Basic study on utterance mean length in Korea 2-4 yearold children. Korean Journal of Communication Disorders, 2(2), 5-25.

Kim, Y. T., Hong, G. H., Kim, K. H., Jang, H. S., \& Lee, J. Y. (2009). Receptive \& expressive vocabulary test (REVT). Seoul: Seoul Community Rehabilitation Center.

Lee, S. B., \& Sim, H. S. (2015). A longitudinal study of utterance length in morphemes as a predictor of treatment outcome in early childhood stuttering. Communication Sciences \& Disorders, 20(2), 189-201.

Leech, K. A., Bernstein-Ratner, N., Brown, B., \& Weber, C. M. (2017). Preliminary evidence that growth in productive language differentiates childhood stuttering persistence and recovery. Journal of Speech, Language, and Hearing Research, 60(11), 3097-3109.

Logan, K., \& Conture, E. (1995). Relationships between length, grammatical complexity, rate, and fluency of conversational utterances in children who stutter. Journal of Fluency Disorders, 20, 35-61.

Manning, W. H., \& DiLollo, A. (2018). Clinical decision making in fluency disorders (4th ed.). San Diego, CA: Plural Publishing.

Miles, S., \& Bernstein-Ratner, N. (2001). Parental language input to children at stuttering onset. Journal of Speech, Language, and Hearing Research, 44(5),
1116-1130.

Muma, J. R. (1971). Syntax of preschool fluent and disfluent speech: a transformational analysis. Journal of Speech and Hearing Research, 14(2), 428-441.

Ntourou, K., Conture, E. G., \& Lipsey, M. W. (2011). Language abilities of children who stutter: a meta-analytical review. American Journal of SpeechLanguage Pathology, 20(3), 163-179.

Rees, D. I., \& Sabia, J. J. (2014). The kid's speech: the effect of stuttering on human capital acquisition. Economics of Education Review, 38, 76-88.

Reilly, S., Onslow, M., Packman, A., Cini, E., Conway, L., Ukoumunne, O. C., ... \& Wake, M. (2013). Natural history of stuttering to 4 years of age: a prospective community-based study. Pediatrics, 132(3), 460-467.

Sim, H. S., Shin, M. J., \& Lee, E. J. (2010). Paradise-Fluency Assessment II. Seoul: Paradise Welfare Foundation.

Wall, M. J. (1980). A comparison of syntax in young stutterers and nonstutterers. Journal of Fluency Disorders, 5(4), 345-352.

Watkins, R. V., \& Yairi, E. (1997). Language production abilities of children whose stuttering persisted or recovered. Journal of Speech, Language, and Hearing Research, 40(2), 385-399.

Watkins, R. V., Yairi, E., \& Ambrose, N. G. (1999). Early childhood stuttering III: initial status of expressive language abilities. Journal of Speech, Language, and Hearing Research, 42(5), 1125-1135.

Watts, A., Eadie, P., Block, S., Mensah, F., \& Reilly, S. (2015). Language ability of children with and without a history of stuttering: a longitudinal cohort study. International Journal of Speech-Language Pathology, 17(1), 86-95.

Weiss, A. L., \& Zebrowski, P. M. (1994). The narrative productions of children who stutter: a preliminary view. Journal of Fluency Disorders, 19(1), 39-63.

Yairi, E., \& Ambrose, N. G. (1999). Early childhood stuttering I: persistency and recovery rates. Journal of Speech, Language, and Hearing Research, 42(5), 1097-1112.

Yairi, E., \& Ambrose, N. G. (2005). Early childhood stuttering for clinicians by clinicians. Austin, TX: Pro-ED.

Yairi, E., Ambrose, N. G., Paden, E. P., \& Throneburg, R. N. (1996). Predictive factors of persistence and recovery: pathways of childhood stuttering. Journal of Communication Disorders, 29(1), 51-77.

Zackheim, C. T., \& Conture, E. G. (2003). Childhood stuttering and speech disfluencies in relation to children's mean length of utterance: a preliminary study. Journal of Fluency Disorders, 28(2), 115-142. 
Soo-Bok Lee, et al. • Language Skills for Predicting Recovery in Childhood Stuttering

Appendix 1. Detailed information on age, stuttering severity, duration of therapy, MLC-W, NDW, case markers (CM), and connective endings (CE)

\begin{tabular}{|c|c|c|c|c|c|c|c|c|c|c|c|c|c|}
\hline No. & Sex & $\begin{array}{c}\text { Age at } \\
\text { initial visit } \\
\text { (mo) }\end{array}$ & $\begin{array}{l}\text { Stuttering } \\
\text { severity }^{\mathrm{a}}\end{array}$ & $\begin{array}{l}\text { Duration of } \\
\text { therapy } \\
\text { (mo) }\end{array}$ & REVT & $\begin{array}{c}\mathrm{NDW}_{-} \\
\text {pre }\end{array}$ & $\begin{array}{c}\mathrm{NDW}_{-} \\
\text {post }\end{array}$ & $\begin{array}{l}\text { MLC- } \\
\text { w_pre }\end{array}$ & $\begin{array}{c}\text { MLC- } \\
\text { w_post }\end{array}$ & $\begin{array}{c}\mathrm{CM}_{-} \\
\text {pre }\end{array}$ & $\begin{array}{l}\mathrm{CM}_{-} \\
\text {post }\end{array}$ & $\begin{array}{l}\mathrm{CE}_{-} \\
\text {pre }\end{array}$ & $\begin{array}{l}\mathrm{CE}_{-} \\
\text {post }\end{array}$ \\
\hline REC1 & Male & 29 & Moderate & 18 & 33 & 39 & 57 & 1.68 & 1.94 & 19 & 6 & 3 & 0 \\
\hline REC2 & Female & 43 & Moderate & 18 & 51 & 71 & 56 & 2.9 & 2.19 & 24 & 18 & 6 & 7 \\
\hline REC3 & Female & 41 & Moderate-severe & 12 & 43 & 67 & 62 & 2.74 & 2.44 & 25 & 14 & 14 & 6 \\
\hline REC4 & Male & 46 & Moderate-severe & 18 & 47 & 76 & 72 & 2.95 & 3.16 & 30 & 29 & 17 & 21 \\
\hline REC5 & Female & 31 & Moderate-severe & 4.5 & 36 & 47 & 60 & 2.02 & 2.51 & 9 & 24 & 1 & 10 \\
\hline REC6 & Male & 50 & Moderate & 4.5 & 47 & 86 & 87 & 3.01 & 3.21 & 18 & 33 & 7 & 11 \\
\hline REC7 & Female & 41 & Moderate-severe & 18 & 56 & 61 & 86 & 1.86 & 3.54 & 12 & 26 & 1 & 16 \\
\hline REC8 & Male & 49 & Moderate & 18 & 54 & 66 & 73 & 2.32 & 2.82 & 10 & 23 & 14 & 15 \\
\hline REC9 & Male & 51 & Moderate-severe & 18 & 72 & 76 & 91 & 2.95 & 3.65 & 20 & 43 & 30 & 11 \\
\hline REC10 & Female & 39 & Moderate-severe & 18 & 50 & 47 & 79 & 1.67 & 3.23 & 6 & 33 & 14 & 13 \\
\hline REC11 & Male & 64 & Moderate & 18 & 68 & 96 & 88 & 3.89 & 3.11 & 34 & 26 & 25 & 8 \\
\hline PER1 & Male & 36 & Severe & 18 & 40 & 60 & 72 & 2.17 & 3.33 & 17 & 28 & 14 & 21 \\
\hline PER2 & Male & 30 & Moderate-severe & 18 & 38 & 39 & 51 & 1.34 & 2.03 & 8 & 13 & 5 & 8 \\
\hline PER3 & Male & 34 & Moderate-severe & 18 & 48 & 30 & 65 & 2.15 & 3.2 & 14 & 17 & 1 & 12 \\
\hline PER4 & Female & 27 & Moderate & 18 & 40 & 36 & 71 & 1.72 & 2.82 & 11 & 23 & 0 & 15 \\
\hline PER5 & Female & 63 & Moderate-severe & 18 & 72 & 53 & 83 & 2.12 & 3.3 & 13 & 8 & 7 & 13 \\
\hline PER6 & Female & 30 & Moderate-severe & 18 & 36 & 41 & 87 & 1.5 & 3.55 & 9 & 25 & 1 & 13 \\
\hline PER7 & Male & 52 & Severe & 18 & 72 & 55 & 79 & 1.98 & 2.44 & 11 & 16 & 1 & 4 \\
\hline
\end{tabular}

NDW= number of different words; MLC-W= mean length of C-unit in word; REVT=Receptive \& Expressive Vocabulary Test (Kim, Hong, Kim, Jang, \& Lee, 2009).

a Stuttering severity score ( 1 =very mild, 2 = mild, 3 = moderate, 4 = moderate-severe, $5=$ severe) measured Paradise-Fluency Assessment II (Sim, Shin, \& Lee, 2010). 


\section{국문초록}

\section{말더듬 회복 여부에 따른 초기 말더듬아동의 언어능력}

이수복 $\cdot$ 이다연 ${ }^{2} \cdot$ 심현섭 ${ }^{2} \cdot$ 임동선 ${ }^{2}$

1우송대학교 언어치료·청각재활학과, ${ }^{20}$ 이화여자대학교 대학원 언어병리학과

배경 및 목적: 초기 말더듬아동의 치료예후를 예측하는 것이 중요하다. 말더듬 회복집단과 지속집단을 판별하는 것은 실제적이고 이 론적으로도 관심이 높지만 두 집단 간에 표면적으로 유사한 점들이 많기 때문에 판별하기가 어렵다. 다양한 요인 중에서 말더듬 치료 후 말더듬 회복 여부를 예측하기 위해 말더듬아동의 언어능력을 초기평가 시점과 18 개월 후에 자발화를 분석하였다. 한국어의 교차언 어적 특징을 살펴보기 위해 의미론적, 구문론적 프로파일을 모두 분석하였다. 방법: 부모-아동의 상호작용 자발화에서 NDW (다른 낱 말수), MLC-w (평균낱말길이), 격조사 빈도, 연결어미 빈도를 초기 평가 시점과 18 개월 시점에 분석하였다. 말더듬 아동들은 간접치료 와 직접치료를 받았다. 통계분석은 반복측정 분산분석(repeated measured ANOVA), Spearman 비모수 상관분석(Spearman nonparametric correlation analysis) 및 다중단계 회귀분석을 사용하여 그룹 간에 언어 예측인자를 탐색하였다. 또한, 구형성 가정을 만족 시키는지 살펴보기 위하여 Mauchly의 구형성 검정을 실시하였다. 결과: 집단 간에 다른 언어 프로파일 특성이 발견되었다. 지속집단은 초기 방문 시 언어수행력이 떨어졌지만, 18 개월 시점에는 격조사 외에는 다른 요소들은 모두 회복집단과 유사한 정도로 향상되었다. 질 적분석에서도 집단 간에 서로 다른 경향을 보여, 격조사는 지속집단을 예측하였으며, 연결어미는 회복집단을 예측하는 것으로 나타났 다. 논의 및 결론: 언어능력이 초기 말더듬아동의 회복과 지속을 예측할 수 있는지, 한국어만의 특성이 있는지를 살펴보았다. 한국어 격조사와 연결어미가 말더듬 회복과 지속을 예측하는 것으로 나타났다. 더불어 다수의 인원으로 추가적인 언어 프로파일 연구가 필요 함을 제안한다.

핵심어: 초기 말더듬, 언어능력, 종단연구, 지속집단, 회복집단

본 논문은 제2저자의 2016년 석사학위 논문을 수정·보완하였음.

\section{ORCID}

이수복(http://orcid.org/0000-0001-6942-4635); 이다연(http://orcid.org/0000-0003-2276-5760); 심현섭(http://orcid.org/0000-0002-4710-3678); 임동선(http://orcid.org/0000-0001-8254-9504) 